\title{
Development of squaraine dyes for photodynamic therapeutical applications: synthesis and study of electronic factors in the dye formation reaction
}

\author{
Kuthanapillil Jyothish, Rekha R. Avirah, and Danaboyina Ramaiah* \\ Photosciences and Photonics, Chemical Sciences and Technology Division, Regional Research \\ Laboratory (CSIR), Trivandrum 695 019, INDIA \\ E-mail: rama@csrrltrd.ren.nic.in ord_ramaiah@rediffmail.com
}

Dedicated to Professor Waldemar Adam on the occasion of his $\mathbf{7 0}^{\text {th }}$ birthday

\begin{abstract}
With a view to developing sensitizers for applications in photodynamic therapy (PDT), a series of quinaldine based squaraine dyes have been synthesized and the role of electronic factors in the dye formation have been investigated through absorption spectroscopy, product analysis and theoretical calculations. It has been observed that semisquaraine intermediates were formed as the sole products in the reaction of quinaldinium salts containing electron-donating substituents with squaric acid. However, with salts possessing electronegative and electron-withdrawing groups, the squaraine dyes were isolated in quantitative yields. The semisquaraine intermediates that have been isolated as the butyl adducts, could be converted to the squaraine dyes by reacting with the quinaldinium salts having electronegative and / or electron-withdrawing groups. These dyes exhibit absorption in the range $700-800 \mathrm{~nm}$ with significant molar extinction coefficients $(\varepsilon$ $=1-3 \times 10^{5} \mathrm{M}^{-1} \mathrm{~cm}^{-1}$ ) and hence can have potential PDT applications.
\end{abstract}

Keywords: Photodynamic therapy, quinaldine, semisquaraine, sensitizer, squaraine dye

\section{Introduction}

Photodynamic therapy (PDT) is an emerging modality for the diagnosis and treatment of cancer and related diseases. ${ }^{1,2}$ PDT involves the inactivation of living cells by the combined action of light and a chemical (photosensitizer). After intravenous injection, the tumor tissues selectively retain the photosensitizer and when exposed to light of a specific wavelength, it generates highly reactive species. These reactive species damage cellular constituents and eventually cause cell death. PDT is relatively a safer treatment since the induction of cytotoxicity ceases when the light is switched off, contrary to the conventional chemotherapy and radiotherapy. Several 
photosensitizers have been investigated for their use in PDT. These include, porphyrins, chlorins, benzoporphyrins, benzoporphycenes, phthalocyanins, purpurins, and aminolevulinic-acidmediated porphyrins etc. ${ }^{3-5}$ Of these sensitizers, hematoporphyrin derivative $(\mathrm{HpD})$ and its commercial variants have been approved for the treatment of various types of tumors in a number of countries. ${ }^{6}$ However, these sensitizers have several disadvantages and hence the search for more effective sensitizers has become important in recent years.

Our objective has been to explore the potential use of squaraines as photosensitizers in PDT applications. Squaraines form a novel class of dyes possessing sharp and intense absorption bands in the red to near infrared region. ${ }^{7}$ The photophysical and photochemical properties of these dyes have been studied extensively, ${ }^{8-13}$ because their absorption and fluorescence characteristics make them highly suitable for a number of industrial applications. These include, as sensitizers in optoelectronic and imaging systems, ${ }^{9}$ organic solar cells, ${ }^{10}$ second harmonic generation, ${ }^{11}$ sensors for metal ions, ${ }^{12}$ and proteins. ${ }^{13}$ However, due to the negligible intersystem crossing efficiency of these dyes, their potential as sensitizers in photodynamic therapy (PDT) has not yet been explored.

We have reported earlier a few heavy atom substituted squaraine dyes, $\mathbf{3 a}$ and $\mathbf{3 b}$ based on the phloroglucinol moiety and their photophysical and in vitro photobiological properties under different conditions (Scheme 1) ${ }^{14}$ Introduction of the heavy atoms such as bromine and iodine resulted in increased water solubility and intersystem crossing efficiency when compared to the parent unsubstituted squaraine dye $\mathbf{2}$. Triplet excited states were the main transients involved in these systems $\left(\left(\phi_{\mathrm{T}}=0.3-0.5\right)\right.$, which interact efficiently with molecular oxygen generating biologically highly reactive singlet oxygen in significant yields $\left[\phi\left({ }^{1} \mathrm{O}_{2}\right)=0.22-0.47\right]$. The photobiological studies indicated high photocytotoxicity of $\mathbf{3 a}$ and $\mathbf{3 b}$ with relatively little toxicity in the dark as compared to the squaraine dye $2 .{ }^{15}$ However, the absorption exhibited by the halogenated squaraine dyes 3a and $\mathbf{3 b}$ (around $600 \mathrm{~nm}$ ) is not optimum since most of the biological tissues also have significant absorption at this wavelength. Due to these reasons, the use of these compounds for the destruction of deep-seated tumors becomes difficult. This prompted us to design new sensitizers with improved photophysical and photobiological properties. We felt that quinaldine-based squaraine dyes could serve as efficient sensitizers because these dyes are expected to have absorption in the long-wavelength region $(>700 \mathrm{~nm})$ with high extinction coefficients $\left(>10^{5} \mathrm{M}^{-1} \mathrm{~cm}^{-1}\right){ }^{16}$

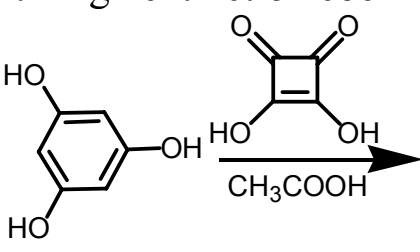

1

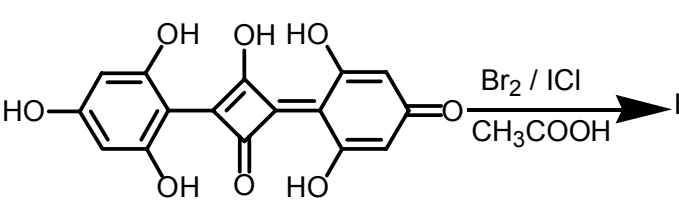

2

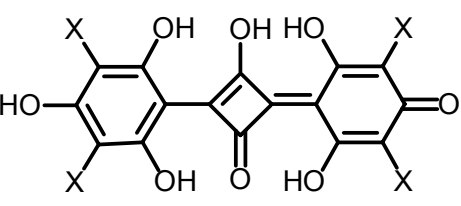

3a-b a) $X=B$ b) $X=1$

\section{Scheme 1}


Moreover, the benzene ring of the quinaldine moiety can be suitably modified so as to improve their quantum yields of triplet excited states and cellular pharmacokinetics thereby their potential PDT applications.

\section{Results and Discussion}

Squaraine dyes are usually prepared by the condensation reaction between squaric acid and electron-rich aromatic, heteroaromatic, or olefinic compounds in a one-step reaction. ${ }^{16-18}$ Following the same strategy, we have carried out the reaction between the quinaldinium salt 4a and squaric acid in 2:1 equivalents, respectively, in a mixture (1:1) of benzene and n-butanol (Scheme 2). Since squaraine dyes in general are brightly colored compounds with absorption in the near infrared region, we monitored the progress of the reaction by absorption spectroscopy in addition to the thin layer chromatography. No absorption band in the near infrared region was observed during the initial stages of the reaction. However, an absorption band around $485 \mathrm{~nm}$ was observed within $4 \mathrm{~h}$ of the reaction and this band increased in intensity with reaction time. The reaction mixture following work up and column chromatography after $30 \mathrm{~h}$, gave the semisquaraine 5a (90\%) as the major product. We assigned the species with absorption at 485 $\mathrm{nm}$ to the butyl adduct of the semisquaraine intermediate. Similar observations were made when the condensation reactions were carried out with the quinaldinium salts $\mathbf{4 b}$ and $\mathbf{4 c}$, and squaric acid (Scheme 2). The reaction did not result in the formation of the corresponding squaraine dyes, instead, only butyl adducts of the semisquaraine intermediates $\mathbf{5 b}$-c were isolated in 90$95 \%$ yields.

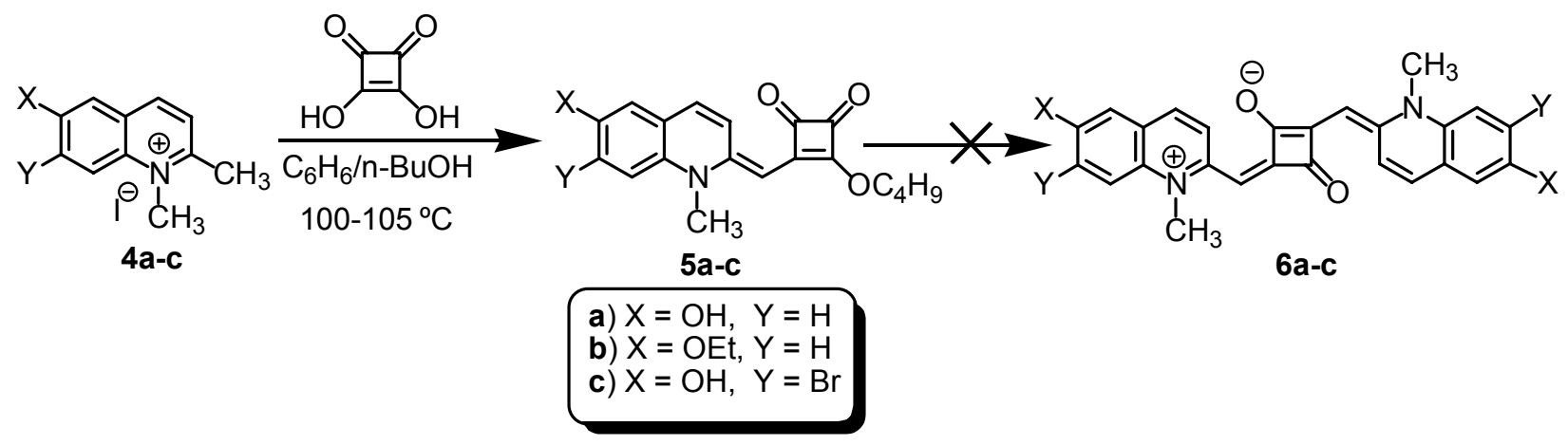

\section{Scheme 2}

To investigate the effect of substituents on the formation of the semisquaraine intermediates, we have synthesized substituted quinaldinium salts 4d-h (Scheme 3), and monitored the dye formation reaction. The reaction of the quinaldinium salt $\mathbf{4 d}$ with squaric acid under analogous conditions gave the corresponding squaraine dye $\mathbf{6 d}$ in $85 \%$ yield through the intermediacy of the semisquaraine 5d. The absorption spectra recorded at various reaction time intervals, showed 
the formation of the semisquaraine intermediate $\mathbf{5 d}\left(\lambda_{\max } 485 \mathrm{~nm}\right)$ and the squaraine dye $\mathbf{6 d}\left(\lambda_{\max }\right.$ $714 \mathrm{~nm}$ ) with an isosbestic point at $540 \mathrm{~nm}$. As the reaction progresses, the absorption band at $485 \mathrm{~nm}$ decreases with a concomitant increase in the absorption around $714 \mathrm{~nm}$, indicating that the species having absorption at $485 \mathrm{~nm}$ is an intermediate in the dye forming reaction. Similar observations were made with the quinaldinium salts substituted with halogens (4e and $\mathbf{4 f}$ ) and electron-withdrawing nitro (4g) and cyano (4h) groups. These salts on reaction with squaric acid gave their corresponding squaraine dyes 6e-h in 84-96\% yields (Scheme 3), which were characterized on the basis of spectral data and analytical results.

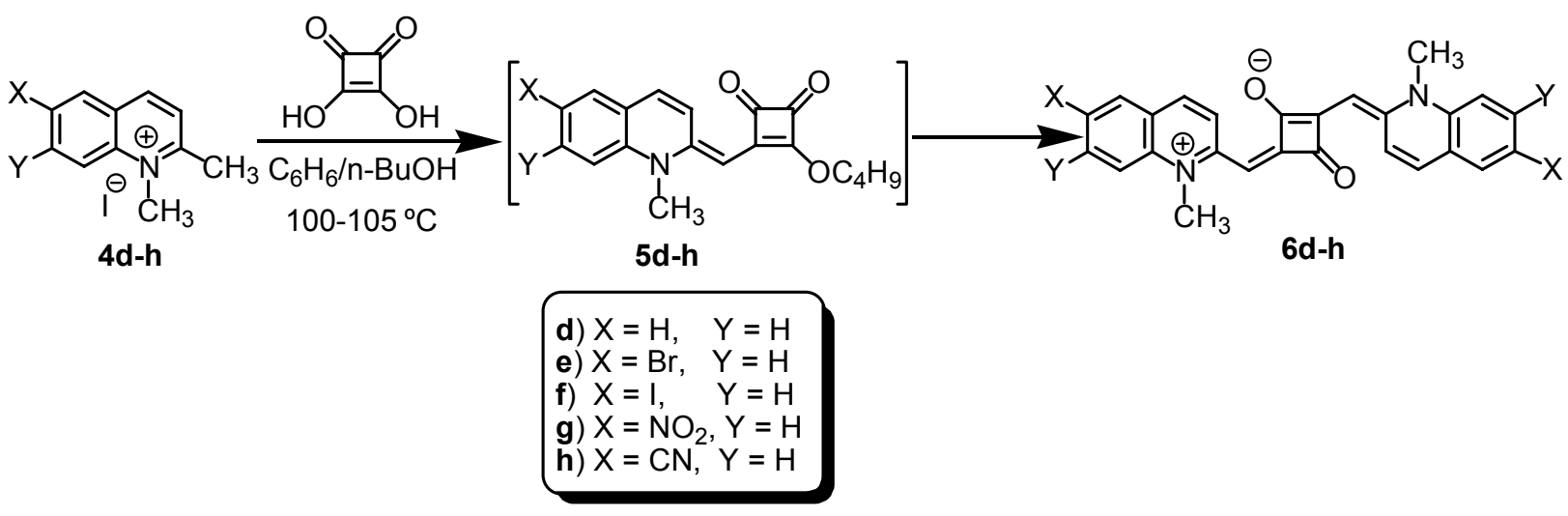

\section{Scheme 3}

With the objective of improving the biological uptake of these dyes, we have substituted with cellular recognition elements such as sugar and cholesterol moieties. As shown in scheme 4, the reaction of the sugar linked quinaldinium salts $\mathbf{4 i}$ and $\mathbf{4 j}$ with squaric acid under identical conditions gave the corresponding semisquaraine intermediates $\mathbf{5 i}$ and $\mathbf{5 j}$ as the major products $(>80 \%)$, along with small amounts of the squaraine dyes $\mathbf{6 i}$ and $\mathbf{6 j} \mathbf{j}(<10 \%)$. Further, the reaction of the sugar linked semisquaraine intermediates $\mathbf{5 i}$ and $\mathbf{5 j}$ with 6 -iodoquinaldinium salt (4f) in a mixture $(1: 1)$ of $n$-butanol and benzene led to the formation of the corresponding unsymmetrical squaraine dyes $\mathbf{7 i - j}$ in quantitative yields. Similarly, the condensation between squaric acid and the cholesterol linked quinaldinium salt $4 \mathbf{k}$ in 1:2 equivalents gave the symmetrical squaraine dye $\mathbf{6 k}$ in quantitative yields $(85 \%)$, while the semisquaraine $\mathbf{5 k}$ was isolated as the minor product $(<5 \%)$. The formation of the cholesterol linked squaraine dye $6 \mathbf{k}$ in quantitative yields indicates that the electron withdrawing appendage significantly decreases the electron donating effect of the hydroxyl group. The synthesis of the unsymmetrical squaraine dye $7 \mathbf{k}$ was achieved in quantitative yields from the condensation reaction of the semisquaraine derivative $\mathbf{5 k}$. However, the semisquaraine intermediate $\mathbf{5 k}$ was prepared in quantitative yields from an independent reaction between the stable semisquaraine intermediate 5a and cholesteryl chloroformate (Scheme 5). Subsequent condensation of the semisquaraine intermediate 5k with 6-iodoquinaldinium salt (4f) gave $80 \%$ of the unsymmetrical squaraine dye $7 \mathbf{k}$. 


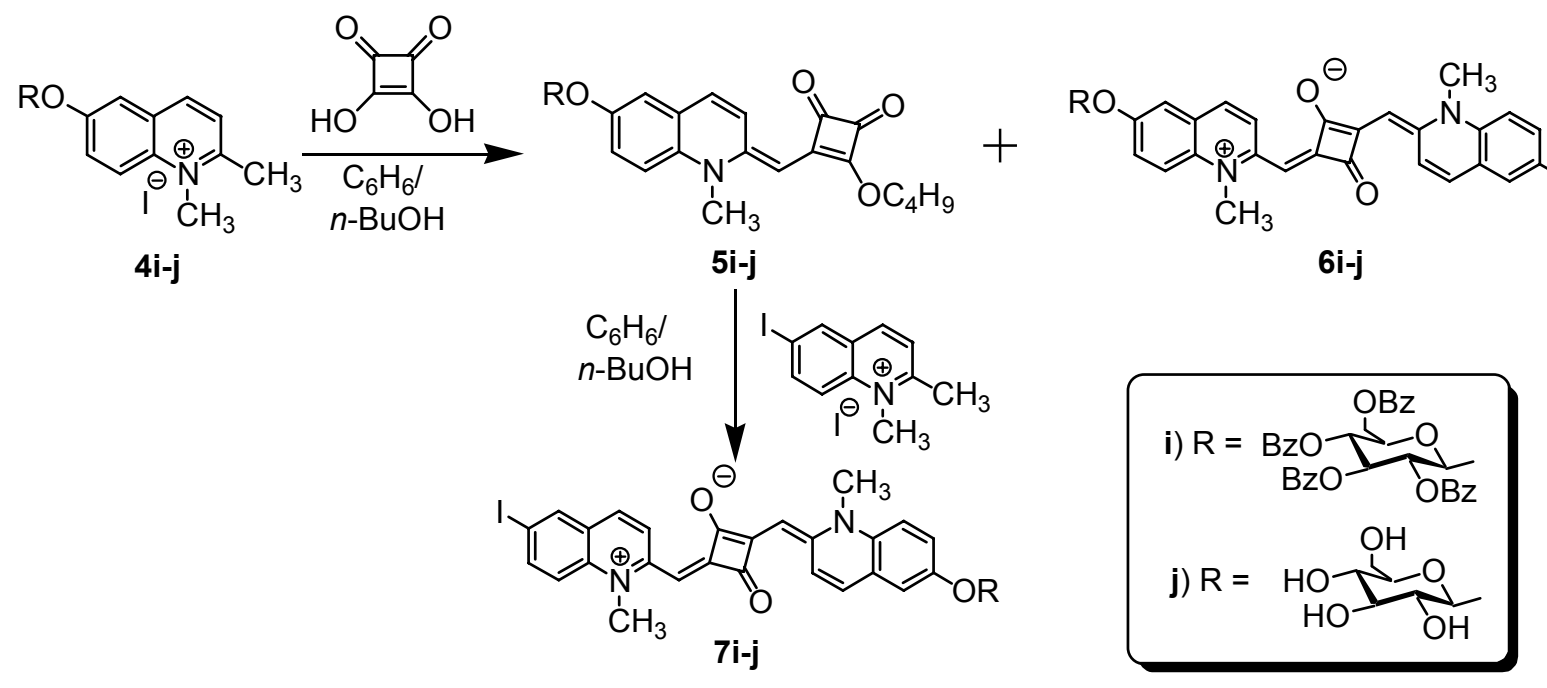

\section{Scheme 4}

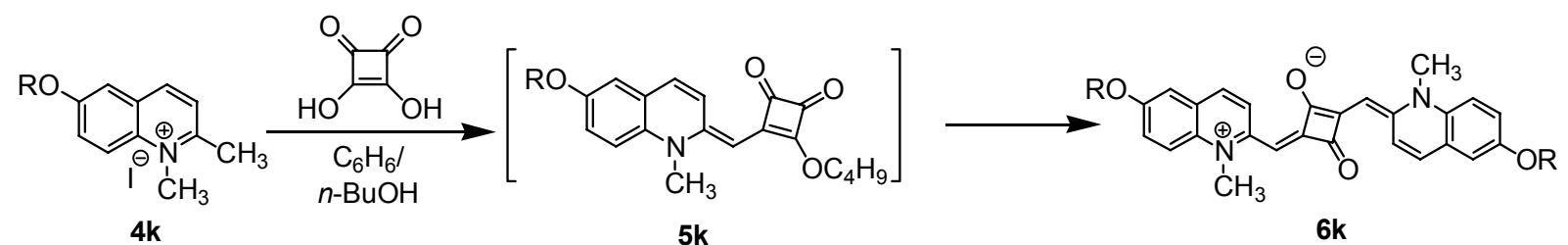

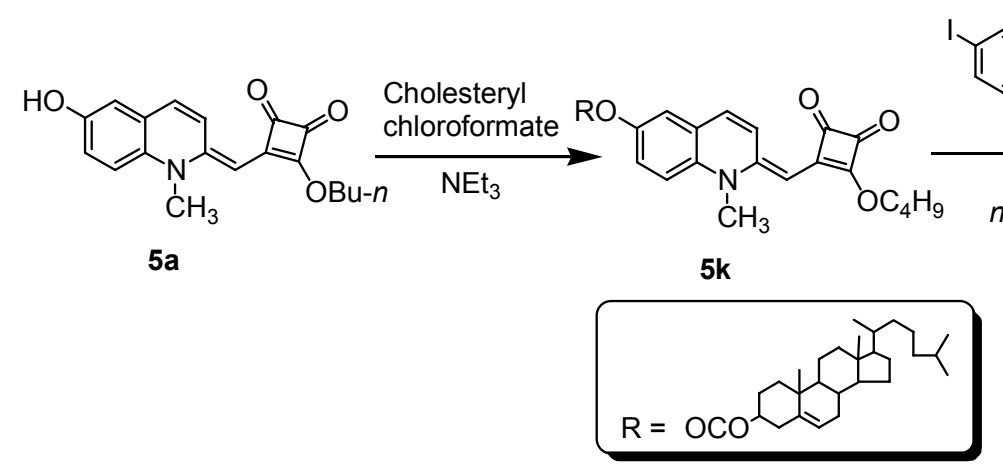

\section{Scheme 5}

The variation in the reactivity of the substituted quinaldinium salts $\mathbf{4 a - k}$ in the dye reaction can be explained on the basis of the electronic effects of various substituents. Squaraine dye forming reaction involves the reaction between an electron rich aromatic derivative and squaric acid. The success of the reaction depends mainly on the nucleophilicity of the aryl species. In the present study, the nucleophile is an enamine formed from the quinaldinium salt, which reacts with squaric acid resulting in the formation of the semisquaraine. Subsequently, the semisquaraine undergoes further reaction with another moiety of the enamine to give the squaraine dye. The presence of electron-donating groups on the benzene ring of the quinaldinium salts $\mathbf{4 a - c}$ and $\mathbf{4} \mathbf{i}-\mathbf{j}$ reduces the acidity of the hydrogen atoms of the 2-methyl group and thereby 
decreasing the formation of the enamine nucleophile. Nevertheless, the enamine formed reacts with squaric acid resulting in the corresponding semisquaraines 5a-c and $\mathbf{5 i}$-j. Furthermore, the electrophilic terminus of these semisquaraines is rendered less reactive by the electron-donating substituents and hence further reaction with the less acidic salts becomes extremely difficult. As a result, the reaction stops with the formation of the semisquaraine only in the case of the salts 4a-c and 4i-j. However, in the presence of electronegative (4e,f) and electron-withdrawing substituents $(\mathbf{4 g}, \mathbf{h})$, the hydrogen atoms of the 2-methyl group are relatively more acidic and thereby favors the formation of the enamine nucleophile very efficiently. These salts yield higher concentrations of the nucleophile and hence results in the formation of the corresponding squaraine dyes 6e-h in quantitative yields through the intermediacy of the semisquaraine intermediates $\mathbf{5 e - h}$.



4a

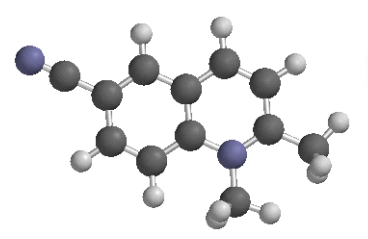

4h

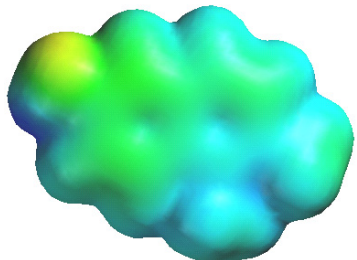

$4 a$

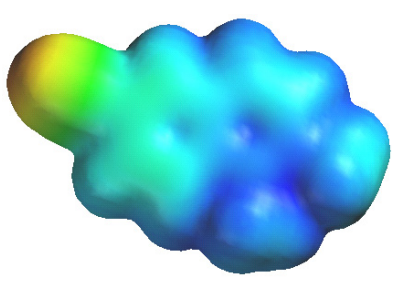

4h

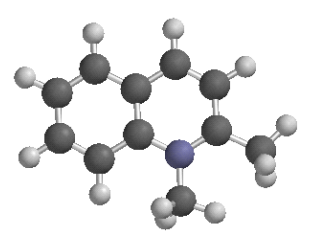

4d

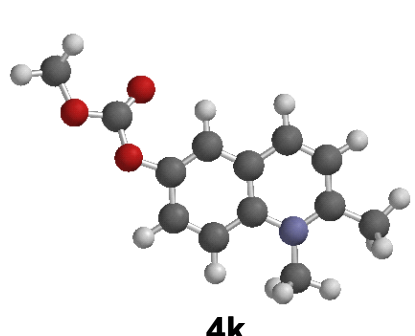

4k

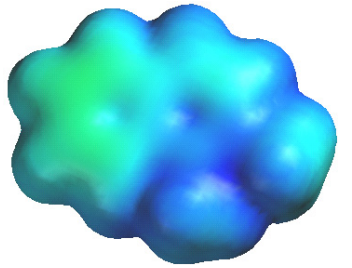

4d

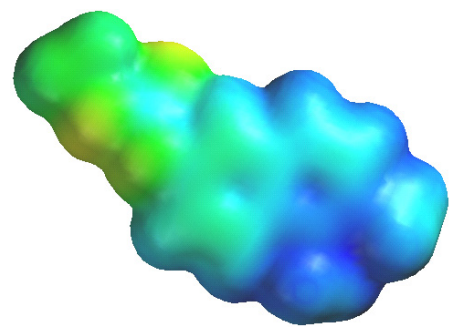

4k

Figure 1. Electrostatic potential maps of the quinaldinium salts $\mathbf{4 a}, \mathbf{4 d}, \mathbf{4 h}$ and $\mathbf{4 k}$ (cholesterol moiety is replaced with methyl) obtained using TITAN software. ${ }^{19}$

Molecular modeling studies have been carried out using TITAN $^{19}$ to further understand the mechanism of dye forming reaction. We selected a few quinaldinium salts (4a, 4d, $4 \mathbf{h}$ and $4 \mathbf{k}$; Figure1) substituted with electron-donating and withdrawing groups and two semisquaraine intermediates $\mathbf{5 a}$ (obtained from the least reactive quinaldinium salt) and $\mathbf{5} \mathbf{h}$ (obtained from the most reactive quinaldinium salt) for the comparison. Starting from a fully optimized geometry, the electrostatic potential was calculated. The color at each point on these surfaces reflects the interaction energy between a positive test charge at that point. Red indicates an attractive potential while blue represents a repulsive potential. The areas of red therefore indicate a "negative" region; yellow/green indicates a more neutral or "positive" region, depending on how bluish is the color. The area around the 2-methyl group in $\mathbf{4 a}$ is greenish in color, whereas it is 
quite bluish in the case of $\mathbf{4 d}, \mathbf{4 h}$ and $\mathbf{4 k}$. This is consistent with the fact that the acidity of the 2methyl protons increases as the electron withdrawing power of the substituent increases, which favors the formation of the squaraine dye, as observed in the case of $\mathbf{4 d}, \mathbf{4 h}$ and $\mathbf{4 k}$. Similarly, in the case of the semisquaraine intermediate 5a, the squaryl ring is yellowish green in color, whereas it is strongly bluish in the case of $\mathbf{5 h}$ (Figure 2). These results confirm the fact that the presence of electron-donating substituents increases the electron density in the squaryl ring, and thereby stabilizes the semisquaraine intermediate. Therefore, a further condensation reaction between the semisquaraine having weak electrophilic termini and a weak nucleophilic quinaldinium salt becomes extremely difficult, as observed in the case of the semisquaraine intermediate 5a.

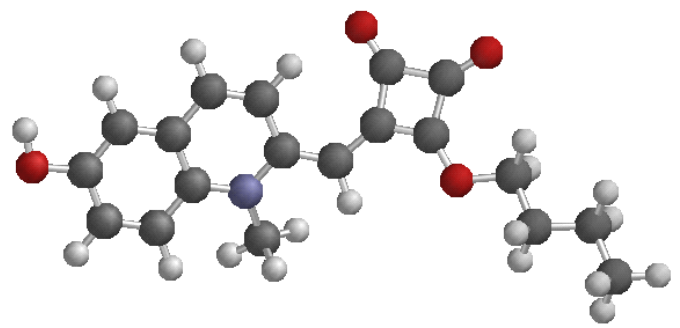

$5 \mathbf{a}$



$5 h$


Figure 2. Electrostatic potential maps of the representative semisquaraine intermediates $\mathbf{5 a}$ and 5h obtained through TITAN software. ${ }^{19}$

To have a better understanding of potential PDT applications, we investigated the absorption and fluorescence properties of a few derivatives under different conditions (Table 1). The semisquaraines found to exhibit absorption in the range $450-550 \mathrm{~nm}$, while highly red-shifted absorption $\lambda_{\max }$ ranging from $739-751 \mathrm{~nm}$ was observed for the squaraine dyes. These dyes showed significant molar extinction coefficients in the range $\varepsilon=0.85 \sim 2.8 \times 10^{5} \mathrm{M}^{-1} \mathrm{~cm}^{-1}$ and structurally similar fluorescence emission spectra with a maximum around $765 \mathrm{~nm}$. 
Table 1. Absorption properties of the representative semisquaraines and squaraine dyes ${ }^{\mathrm{a}}$

\begin{tabular}{lcccccc}
\hline Compound & $\mathbf{5 a}^{\mathrm{b}}$ & $\mathbf{5 b}^{\mathrm{c}}$ & $\mathbf{6 f ^ { \mathrm { d } }}$ & $\mathbf{6 i}^{\mathrm{e}}$ & $\mathbf{7 j}^{\mathrm{d}}$ & $\mathbf{7 k}^{\mathrm{e}}$ \\
\hline $\begin{array}{l}\text { Absorption } \\
\left(\lambda_{\max }, \mathrm{nm}\right)\end{array}$ & 476 & 506 & 751 & 746 & 751 & 743 \\
$\varepsilon, 10^{5} \mathrm{M}^{-1} \mathrm{~cm}^{-1}$ & 0.41 & 0.29 & 1.3 & 1.7 & 0.85 & 2.8 \\
\hline
\end{tabular}

${ }^{\mathrm{a}}$ Average of more than two experiments, ${ }^{\mathrm{b}}$ methanol, ${ }^{\mathrm{c}}$ acetone, ${ }^{\mathrm{d}} \mathrm{DMSO},{ }^{\mathrm{e}}$ chloroform.

\section{Conclusions}

In conclusion, we have demonstrated that substitution on the benzene ring of the quinaldine moiety can affect the reaction between the quinaldinium salts and squaric acid resulting in the formation of the corresponding squaraine dyes. The quinaldinium salts with electron-donating substituents hinder the formation of the dye and results only in the formation of the semisquaraine, while electronegative and electron-withdrawing substituents facilitate the formation of the corresponding squaraine dyes with the intermediacy of the corresponding semisquaraines. We have further demonstrated the synthesis of a few symmetrical and unsymmetrical squaraine dye conjugates with cellular recognition elements by making use of favorable electronic effects of substituents. These dyes show sharp and intense absorption in the long wavelength region $(700-800 \mathrm{~nm})$, and exhibit structurally similar fluorescence emission. Their intense absorption in the photodynamic window and the presence of cellular recognition elements such as sugar, cholesterol and heavy atoms like iodine would increase their cellular pharmacokinetics and singlet oxygen efficiency; hence these dyes can serve as efficient sensitizers in PDT applications.

\section{Experimental Section}

General Procedures. The equipment and procedure for spectral recordings are described elsewhere. ${ }^{20}$ All melting points are uncorrected and were determined on a Mel-Temp II melting point apparatus. The IR spectra were recorded on a Perkin Elmer Model 882 infrared spectrometer. The electronic absorption spectra were recorded on a Shimadzu UV-3101 or 2401 PC UV-VIS-NIR scanning spectrophotometer. ${ }^{1} \mathrm{H}$ and ${ }^{13} \mathrm{C}$ were measured on a $300 \mathrm{MHz}$ Bruker advanced DPX spectrometer. All the solvents used were purified and distilled before use. The progress of the reaction was monitored by recording absorption spectrum of the reaction mixture at various time intervals. For this $25 \mu \mathrm{L}$ of the reaction mixture was taken out and diluted to 3 $\mathrm{mL}$ and recorded the absorption spectra. 
Materials. 6-Hydroxy-2-quinaldine (mp 262-264 $\left.{ }^{0} \mathrm{C}\right),{ }^{21}$ 6-ethoxy-2-quinaldine $\left(\mathrm{mp} 71-72{ }^{0} \mathrm{C}\right),{ }^{21}$ 6-hydroxy-7-bromo-2-quinaldine (mp 235-237 $\left.{ }^{\circ} \mathrm{C}\right),{ }^{21}$ 6-iodo-2-quinaldine $\left(\mathrm{mp} 108-109{ }^{0} \mathrm{C}\right),{ }^{21} 6$ bromo-2-quinaldine $\left(\mathrm{mp} \mathrm{95-96}{ }^{0} \mathrm{C}\right),{ }^{21}$ 6-nitro-2-quinaldine $\left(\mathrm{mp} \mathrm{165-166}{ }^{0} \mathrm{C}\right),{ }^{21}$ 6-hydroxy- $\mathrm{N}$ methyl-2-quinaldinium iodide (4a, mp 238-239 $\left.{ }^{0} \mathrm{C}\right),{ }^{21}$ 6-ethoxy- $N$-methyl-2-quinaldinium iodide (4b, mp 182-183 $\left.{ }^{\circ} \mathrm{C}\right),{ }^{21} \mathrm{~N}$-methyl-2-quinaldinium iodide (4d, mp 195-196 $\left.{ }^{0} \mathrm{C}\right),{ }^{21}$ 6-bromo- $N$ methyl-2-quinaldinium iodide $\left(4 \mathrm{e}, \mathrm{mp} 237{ }^{0} \mathrm{C}\right),{ }^{21}$ 6-iodo- $N$-methyl-2-quinaldinium iodide $(\mathbf{4 f}, \mathrm{mp}$ $\left.222-223{ }^{0} \mathrm{C}\right),{ }^{21} 6$-nitro- $N$-methyl-2-quinaldinium iodide $\left(4 \mathrm{~g}, \mathrm{mp} 214-215{ }^{0} \mathrm{C}\right),{ }^{21}$ and the squaraine dye $6 \mathbf{d}\left(\mathrm{mp} 297-298{ }^{0} \mathrm{C}\right),{ }^{16}$ were prepared by modifying the reported procedures.

\section{General procedure for the preparation of quinaldines}

To a refluxing solution of the corresponding aniline derivative $(18 \mathrm{mmol})$ in $6 \mathrm{~N} \mathrm{HCl}(25 \mathrm{~mL})$, crotonaldehyde (72 mmol) was added drop wise over a period of $1 \mathrm{~h}$ and refluxed for $6 \mathrm{~h}$. The reaction mixture was cooled to room temperature, made alkaline using ammonia solution and was then extracted with diethyl ether. Removal of the solvent under reduced pressure gave a residue, which was subjected to column chromatography over silica gel. Elution of the column with a mixture of ethyl acetate and petroleum ether (1:9) gave the corresponding quinaldine derivatives in good yields.

Preparation of 6-cyano-2-quinaldine. A mixture of 6-bromo-2-methylquinoline (600 mg, 2.7 mmol), cuprous cyanide (400 $\mathrm{mg}, 4.5 \mathrm{mmol})$ and pyridine $(6 \mathrm{~mL})$ was heated in a sealed tube at $200{ }^{\circ} \mathrm{C}$ for $24 \mathrm{~h}$. The deep brown solution was shaken with aqueous ammonia and dichloromethane and the organic layer was washed with water. Removal of the solvent gave a residue, which was then subjected to column chromatography over silica gel. Elution of the column with a mixture of ethyl acetate and petroleum ether (1:9) gave $75 \%$ of the quinaldine derivative, mp 168-170 ${ }^{0} \mathrm{C}$, IR $(\mathrm{KBr}) v_{\max } 3031,2224,1619 \mathrm{~cm}^{-1} ;{ }^{1} \mathrm{H}-\mathrm{NMR}\left(\mathrm{CDCl}_{3}\right) \delta 8.17$ $(1 \mathrm{H}, \mathrm{s}), 8.10(2 \mathrm{H}, \mathrm{dd}, \mathrm{J}=11.4 \mathrm{~Hz}), 7.80(1 \mathrm{H}, \mathrm{d}, \mathrm{J}=8.7 \mathrm{~Hz}), 7.40(1 \mathrm{H}, \mathrm{d}, \mathrm{J}=8.5 \mathrm{~Hz}), 2.79(3 \mathrm{H}$, $\mathrm{s}) ;{ }^{13} \mathrm{C}$ NMR (DMSO-d $\left.{ }_{6}\right) \delta 162.5,148.8,136.2,133.7,130.2,130.1,125.8,123.7,118.6,109.3$, 25.6.

Preparation of 6-tetra- $\boldsymbol{O}$-benzoyl- $\beta$-D-glucopyranose-2-methylquinoline. To a solution of 6 hydroxyquinaldine (500 mg, $3.14 \mathrm{mmol}$.) in $15 \mathrm{~mL}$ of $1 \mathrm{M} \mathrm{NaOH}$, tetrabutylammonium bromide $(1.01 \mathrm{~g}, 3.14 \mathrm{mmol})$ and 2,3,4,5-tetra- $O$-benzoyl- $\beta$-D-glucopyranosyl bromide $(2.03 \mathrm{~g}, 3.14$ $\mathrm{mmol}$ ) in $15 \mathrm{~mL} \mathrm{CHCl}_{3}$ was added drop wise with vigorous stirring for $3 \mathrm{~h}$. The reaction mixture was diluted with $10 \mathrm{~mL} \mathrm{CHCl}$, the organic layer was separated and washed with water. Removal of the solvent gave a residue, which was subjected to column chromatography over silica gel. Elution of the column with a mixture of ethyl acetate and petroleum ether (1:9) gave $20 \%$ of the quinaldine derivative, (mp 107-108 ${ }^{0} \mathrm{C}$ ), IR (KBr) $v_{\max } 2976,1740,1612 \mathrm{~cm}^{-1} ;{ }^{1} \mathrm{H}$ NMR $\left(300 \mathrm{MHz}, \mathrm{CDCl}_{3}\right) \delta$ 8.03-7.87 (9H, m), 7.59-7.13 (16H, m), 6.07-5.58 (4H, m), 4.78-4.47 $(3 \mathrm{H}, \mathrm{m}), 2.67(3 \mathrm{H}, \mathrm{s}) ;{ }^{13} \mathrm{C} \mathrm{NMR}\left(75 \mathrm{MHz}, \mathrm{CDCl}_{3}\right) \delta 156.1,155.7,155.3,148.4,146.0,135.2$, $126.1,123.8,120.1,120.0,119.0,118.7,118.1,115.8,113.2,110.4,96.3,71.1,70.9,68.1,61.0$, 22.9. 
Preparation of 6- $\beta$-D-glucopyranose-2-quinaldine. A mixture of 6-tetra- $O$-benzoyl- $\beta$-Dglucopyranose-2-methylquinoline in dry methanol and sodium methoxide was stirred at room temperature for $12 \mathrm{~h}$. The reaction mixture was poured into ice water, and extracted with ethyl acetate. Removal of the solvent gave a residue, and the products were separated by column chromatography over silica gel. Elution of the column with a mixture of methanol and ethyl acetate (1: 9) gave $90 \%$ of the deprotected quinaldine derivative, mp 161-162 ${ }^{\circ} \mathrm{C}$, IR (KBr) $v_{\max }$ 3527, 3273, 2920, $1575 \mathrm{~cm}^{-1} ;{ }^{1} \mathrm{H}$ NMR $\left(300 \mathrm{MHz}, \mathrm{CDCl}_{3}: \mathrm{MeOH}-\mathrm{d}_{4}\right) \delta 8.11(1 \mathrm{H}, \mathrm{d}, \mathrm{J}=8.4 \mathrm{~Hz})$, $7.91(1 \mathrm{H}, \mathrm{d}, \mathrm{J}=9.1 \mathrm{~Hz}), 7.51(1 \mathrm{H}, \mathrm{d}, \mathrm{J}=9.3 \mathrm{~Hz}), 7.43(1 \mathrm{H}, \mathrm{s}), 7.34(1 \mathrm{H}, \mathrm{d}, \mathrm{J}=8.4 \mathrm{~Hz}), 5.07-$ 5.03 (1H, m), 3.98- $3.94(1 \mathrm{H}, \mathrm{m}), 3.81-3.78(1 \mathrm{H}, \mathrm{m}), 3.58-3.54(3 \mathrm{H}, \mathrm{m}), 3.34(1 \mathrm{H}, \mathrm{s}), 2.7(3 \mathrm{H}, \mathrm{s})$; ${ }^{13} \mathrm{C}$ NMR $\left(75 \mathrm{MHz}, \mathrm{CDCl}_{3}: \mathrm{CD}_{3} \mathrm{OD}\right) \delta 158.3,156.3,156.0,144.7,137.6,129.5,128.6,123.7$, 123.6, 111.7, 102.2, 74.6, 71.2, 62.4, 24.6, 24.2 .

Preparation of 6-cholesteryl-2-quinaldine. A mixture of 6-hydroxyquinaldine (100 mg, 0.63 mmol), cholesteryl chloroformate $(450 \mathrm{mg}, 1 \mathrm{mmol})$ and pyridine $(5 \mathrm{~mL})$ were heated at $60{ }^{0} \mathrm{C}$ for $12 \mathrm{~h}$. Removal of the solvent gave a residue, which was then subjected to column chromatography over silica gel. Elution of the column with a mixture of ethyl acetate and petroleum ether (1:9) gave $85 \%$ of the corresponding quinaldine derivative, $\mathrm{mp} 101-102{ }^{0} \mathrm{C}$, IR $(\mathrm{KBr}) v_{\max } 2945,1753,1606 \mathrm{~cm}^{-1} ;{ }^{1} \mathrm{H}$ NMR $\left(300 \mathrm{MHz}, \mathrm{CDCl}_{3}\right) \delta 8.02-7.95(2 \mathrm{H}, \mathrm{m}), 7.61(1 \mathrm{H}$, s), $7.52(1 \mathrm{H}, \mathrm{d}, \mathrm{J}=9.1 \mathrm{~Hz}), 7.43(1 \mathrm{H}, \mathrm{d}, \mathrm{J}=9.1 \mathrm{~Hz}), 5.34(1 \mathrm{H}, \mathrm{s}), 4.61(1 \mathrm{H}, \mathrm{s}), 2.74(3 \mathrm{H}, \mathrm{s})$, 2.04-0.67 (43H, m); ${ }^{13} \mathrm{C}$ NMR (75 MHz, $\left.\mathrm{CDCl}_{3}\right) \delta 157.8,151.9,147.5,144.2,139.8,138.1$, $135.4,128.7,125.6,124.3,122.3,121.8,121.6,120.6,116.6,78.2,70.7,55.8,55.7,55.1,49.0$, $41.3,38.7,38.5,35.8,35.2,34.8,30.9,30.8,27.2,27.0,23.3,22.8,21.8,21.5,20.0,18.3,17.7$, 10.8 .

\section{General procedure for the preparation of the quinaldinium salts}

A mixture of the corresponding quinaldine $(1 \mathrm{mmol})$ and methyl iodide $(4 \mathrm{mmol})$ was heated in a sealed tube at $100-105{ }^{\circ} \mathrm{C}$ for $12 \mathrm{~h}$. The precipitate formed was filtered, washed thoroughly with cold diethyl ether and subjected to column chromatography over silica gel. Elution of the column with a mixture of methanol and chloroform (1:4) gave the corresponding quinaldinium salts $\mathbf{4 a - k}$ in quantitative yields.

4c. $\left(55 \%\right.$, mp $\left.296-297{ }^{0} \mathrm{C}\right),{ }^{1} \mathrm{H}-\mathrm{NMR}\left(\mathrm{DMSO}_{6}\right) \delta 8.68(1 \mathrm{H}, \mathrm{s}), 8.61(1 \mathrm{H}, \mathrm{d}, \mathrm{J}=8.5 \mathrm{~Hz}), 7.76$ $(1 \mathrm{H}, \mathrm{d}, \quad \mathrm{J}=8.5 \mathrm{~Hz}), 7.28(1 \mathrm{H}, \mathrm{s}), 4.24(3 \mathrm{H}, \mathrm{s}), 2.91(3 \mathrm{H}, \mathrm{s}) ;{ }^{13} \mathrm{C}$ NMR $\left(\mathrm{DMSO}^{\left.-\mathrm{d}_{6}\right)} \delta 159.4\right.$, $154.4,142.0,131.3,129.9,126.8,124.2,122.5,109.9,38.6,22.1$.

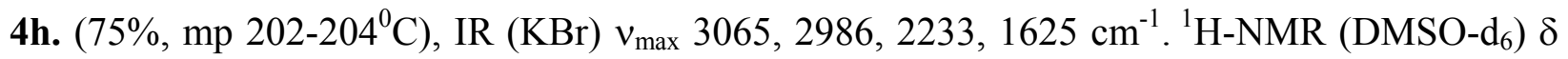
$9.40(1 \mathrm{H}, \mathrm{s}), 9.32(1 \mathrm{H}, \mathrm{d}, \mathrm{J}=8.5 \mathrm{~Hz}), 8.82(2 \mathrm{H}, \mathrm{d}, \mathrm{J}=9.8 \mathrm{~Hz}), 8.29(1 \mathrm{H}, \mathrm{d}, \mathrm{J}=8.7 \mathrm{~Hz}), 4.50(3 \mathrm{H}$, s), $3.1(3 \mathrm{H}, \mathrm{s}) ;{ }^{13} \mathrm{C}$ NMR $\left(\mathrm{DMSO}_{-} \mathrm{d}_{6}\right) \delta 164.5,145.5,140.6,136.2,135.4,127.2,127.0,121.0$, $117.2,111.5,38.7,23.6$

4i. (95\%): $\operatorname{mp} 163-164{ }^{0} \mathrm{C}$; IR (KBr) $v_{\max } 2982,1730,1604 \mathrm{~cm}^{-1} ;{ }^{1} \mathrm{H}$ NMR $\left(300 \mathrm{MHz}, \mathrm{CDCl}_{3}\right) \delta$ $8.86(1 \mathrm{H}, \mathrm{d}, \mathrm{J}=8.7 \mathrm{~Hz}), 8.22(1 \mathrm{H}, \mathrm{s}), 8.06-7.85(11 \mathrm{H}, \mathrm{m}), 7.51-7.30(12 \mathrm{H}, \mathrm{m}), 6.10-6.07(1 \mathrm{H}$, $\mathrm{m}), 5.99-5.96(1 \mathrm{H}, \mathrm{m}), 5.90-5.87(2 \mathrm{H}, \mathrm{m}), 5.02-4.88(1 \mathrm{H}, \mathrm{m}), 4.54-4.51(1 \mathrm{H}, \mathrm{m}), 4.42(3 \mathrm{H}, \mathrm{s})$, $3.01(3 \mathrm{H}, \mathrm{s}) ;{ }^{13} \mathrm{C} \mathrm{NMR}\left(75 \mathrm{MHz}, \mathrm{CDCl}_{3}\right) \delta 166.1,165.8,165.3,158.4,156.0,145.2,136.1$, 
$133.8,133.5,130.1,130.0,128.9,128.1,125.8,120.4,113.2,98.3,73.1,71.9,69.0,62.9,41.5$, 24.9 .

4j. (90\%): $\mathrm{mp} 177-178{ }^{0} \mathrm{C}$; IR (KBr) $v_{\max } 3532,3278,3041 \mathrm{~cm}^{-1}$; ${ }^{1} \mathrm{H}$ NMR (300 MHz, DMSO$\left.\mathrm{d}_{6}\right) \delta 9.12(1 \mathrm{H}, \mathrm{d}, \mathrm{J}=8.4 \mathrm{~Hz}), 8.61(1 \mathrm{H}, \mathrm{d}, \mathrm{J}=9.0 \mathrm{~Hz}), 8.48(1 \mathrm{H}, \mathrm{d}, \mathrm{J}=9.3 \mathrm{~Hz}), 8.12(1 \mathrm{H}, \mathrm{s})$, $7.86(1 \mathrm{H}, \mathrm{d}, \mathrm{J}=8.4 \mathrm{~Hz}), 6.21-6.18(1 \mathrm{H}, \mathrm{m}), 6.11-6.08(1 \mathrm{H}, \mathrm{m}), 5.94-5.87(2 \mathrm{H}, \mathrm{m}), 5.32-5.28$ $(1 \mathrm{H}, \mathrm{m}), 4.96-4.94(1 \mathrm{H}, \mathrm{m}), 4.74-4.70(1 \mathrm{H}, \mathrm{m}), 4.31(3 \mathrm{H}, \mathrm{s}), 3.10(3 \mathrm{H}, \mathrm{s}) ;{ }^{13} \mathrm{C}$ NMR $(75 \mathrm{MHz}$, DMSO-d $\left._{6}\right) \delta 161.1,156.8,146.9,137.3,134.1,128.1,127.3,117.6,99.7,77.0,76.4,73.6,70.7$, $62.1,40.0,22.6$.

4k. (95\%): mp 216-217 ${ }^{0} \mathrm{C}$; IR (KBr) $v_{\max } 1762,1612 \mathrm{~cm}^{-1}$; ${ }^{1} \mathrm{H}$ NMR $\left(300 \mathrm{MHz}, \mathrm{CDCl}_{3}: \mathrm{MeOH}-\right.$ $\left.\mathrm{d}_{4}\right) \delta 8.92(1 \mathrm{H}, \mathrm{d}, \mathrm{J}=8.4 \mathrm{~Hz}), 8.57(1 \mathrm{H}, \mathrm{d}, \mathrm{J}=9.9 \mathrm{~Hz}), 8.17(1 \mathrm{H}, \mathrm{s}), 8.05-8.02(1 \mathrm{H}, \mathrm{m}), 7.47$ $(1 \mathrm{H}, \mathrm{s}), 5.45(1 \mathrm{H}, \mathrm{s}), 4.60(3 \mathrm{H}, \mathrm{s}), 4.59(1 \mathrm{H}, \mathrm{s}), 3.35(3 \mathrm{H}, \mathrm{s}), 2.05-0.71(43 \mathrm{H}, \mathrm{m}) ;{ }^{13} \mathrm{C}$ NMR $(75$ $\left.\mathrm{MHz}, \mathrm{CDCl}_{3}\right) \delta 160.3,151.8,150.7,145.6,138.7,130.0,129.2,126.0,123.4,120.5,120.2,80.1$, 56.6, 56.0, 49.9, 49.1, 48.8, 48.5, 48.2, 48.0, 42.2, 40.6, 39.6, 39.3, 37.7, 36.6, 36.4, 36.0, 35.6, $31.7,28.0,27.8,27.4,24.1,23.6,22.4,22.2,21.1,20.9,19.0,18.4$.

\section{General procedure for the synthesis of the semisquaraine derivatives 5a-c and 5i-k}

A mixture of the corresponding quinaldinium salt $(0.06 \mathrm{mmol})$, squaric acid $(0.06 \mathrm{mmol})$ and quinoline $(0.5 \mathrm{~mL})$ was refluxed in a mixture of $n$-butanol and benzene $(6 \mathrm{~mL}$ each, $1: 1)$ with azeotropic distillation of water for $24 \mathrm{~h}$. The solvent was distilled off under reduced pressure to obtain a residue which was chromatographed over silica gel. Elution of the column with a mixture (1:9) of methanol and chloroform gave the semisquaraine derivatives 5a-j. For synthesizing 5k, the semisquaraine $5 \mathbf{a}(0.03 \mathrm{mmol})$, cholesteryl chloroformate $(0.03 \mathrm{mmol})$ and triethylamine $(1 \mathrm{ml})$ were dissolved in THF $(4 \mathrm{~mL})$ and stirred for $6 \mathrm{~h}$ at $25{ }^{\circ} \mathrm{C}$. The solvent was distilled off under vacuum to obtain a residue, which was then subjected to column chromatography over silica gel. Elution of the column with a mixture (1:9) of methanol and chloroform gave $\mathbf{5 k}$.

5a. $95 \%$ (based on conversion), $\operatorname{mp} 150-152{ }^{\circ} \mathrm{C}$, IR (KBr) $v_{\max } 3412,3042,2963,1761,1606$ $\mathrm{cm}^{-1} .{ }^{1} \mathrm{H}-\mathrm{NMR}\left(\mathrm{CDCl}_{3}+\mathrm{DMSO}_{6}, 4: 1\right) \delta 10.06(1 \mathrm{H}, \mathrm{OH}), 9.29(1 \mathrm{H}, \mathrm{d}, \mathrm{J}=9.4 \mathrm{~Hz}), 7.89(1 \mathrm{H}, \mathrm{d}$, $\mathrm{J}=9.3 \mathrm{~Hz}), 7.73(1 \mathrm{H}, \mathrm{d}, \mathrm{J}=9.4 \mathrm{~Hz}), 7.34(1 \mathrm{H}, \mathrm{d}, \mathrm{J}=9.3 \mathrm{~Hz}), 7.17(\mathrm{IH}, \mathrm{s}), 6.14(1 \mathrm{H}, \mathrm{s}), 4.64$ $(2 \mathrm{H}, \mathrm{t}, \mathrm{J}=6.5 \mathrm{~Hz}), 4.11(3 \mathrm{H}, \mathrm{s}), 1.83-1.74(2 \mathrm{H}, \mathrm{m}), 1.51-1.51(2 \mathrm{H}, \mathrm{m}), 0.99-.89(3 \mathrm{H}, \mathrm{m}) .{ }^{13} \mathrm{C}$ NMR $\left(\mathrm{CDCl}_{3}+\mathrm{DMSO}_{6}, 4: 1\right) \delta 185.2,177.2,175.4,171.5,155.8,152.5,137.4,132.8,127.1$, 124.5, 123.0, 119.4, 111.5, 95.6, 70.8, 37.8, 31.7, 18.2, 13.5; FAB-MS: $\mathrm{m} / \mathrm{z}=325.140$ (calcd 325.139 for $\mathrm{C}_{19} \mathrm{H}_{19} \mathrm{NO}_{4}$ ).

5b. $90 \%$ (based on conversion), $\mathrm{mp} 184-186{ }^{0} \mathrm{C}$, IR (KBr) $v_{\max } 3016,2923,1756,1601 \mathrm{~cm}^{-1} .{ }^{1} \mathrm{H}-$ NMR $\left(\mathrm{CDCl}_{3}\right) \delta 9.41(1 \mathrm{H}, \mathrm{d}, \mathrm{J}=9.3 \mathrm{~Hz}), 7.84(\mathrm{IH}, \mathrm{d}, \mathrm{J}=9.3 \mathrm{~Hz}), 7.63(1 \mathrm{H}, \mathrm{d}, \mathrm{J}=9.4 \mathrm{~Hz}), 7.33$ $(1 \mathrm{H}, \mathrm{d}, \mathrm{J}=9.5 \mathrm{~Hz}), 7.09(1 \mathrm{H}, \mathrm{s}), 6.15(1 \mathrm{H}, \mathrm{s}), 4.71(2 \mathrm{H}, \mathrm{t}, \mathrm{J}=6.6 \mathrm{~Hz}), 4.14(2 \mathrm{H}, \mathrm{t}, \mathrm{J}=6.9 \mathrm{~Hz})$, $4.05(3 \mathrm{H}, \mathrm{s}), 1.79-1.68(5 \mathrm{H}, \mathrm{m}), 1.49-1.47(2 \mathrm{H}, \mathrm{m}), 0.99-0.95(3 \mathrm{H}, \mathrm{m}) .{ }^{13} \mathrm{C} \mathrm{NMR}\left(\mathrm{CDCl}_{3}\right) \delta$ 184.1, 176.3, 174.3, 170.2, 156.6, 153.3, 136.7, 126.6, 125.6, 122.8, 117.4, 109.5, 94.6, 71.9, 63.9, 37.1, 31.8, 18.2, 14.2, 13.5, 13.3; FAB-MS: $\mathrm{m} / \mathrm{z}=353.164$ (calcd 353.163 for $\mathrm{C}_{21} \mathrm{H}_{23} \mathrm{NO}_{4}$ ). 5c. $90 \%$ (based on conversion), $\mathrm{mp} 182-184{ }^{\circ} \mathrm{C}$, IR $(\mathrm{KBr}) v_{\max } 3421,2950,1760,1589 \mathrm{~cm}^{-1} .{ }^{1} \mathrm{H}-$ NMR $\left(\mathrm{CDCl}_{3}+\mathrm{DMSO}_{6}, 4: 1\right) \delta 9.31(1 \mathrm{H}, \mathrm{d}, \mathrm{J}=9.2 \mathrm{~Hz}), 8.12(1 \mathrm{H}, \mathrm{s}), 7.88(1 \mathrm{H}, \mathrm{d}, \mathrm{J}=9.2 \mathrm{~Hz})$, 
$7.3(1 \mathrm{H}, \mathrm{s}), 6.15(1 \mathrm{H}, \mathrm{s}), 4.65(2 \mathrm{H}, \mathrm{t}, \mathrm{J}=6.7 \mathrm{~Hz}), 4.09(3 \mathrm{H}, \mathrm{s}), 1.81-1.76(2 \mathrm{H}, \mathrm{m}), 1.50-1.43(2 \mathrm{H}$, $\mathrm{m}), 0.99-0.94(3 \mathrm{H}, \mathrm{m}) .{ }^{13} \mathrm{C} \mathrm{NMR}\left(\mathrm{CDCl}_{3}\right) \delta 185.8,177.3,175.4,172.0,156.2,136.2,133.3$, 126.1, 124.5, 123.2, 118.0, 111.4, 97.8, 71.8, 38.8, 31.5, 18.1, 13.3; FAB-MS: $\mathrm{m} / \mathrm{z}=404.256$ (calcd 404.255 for $\mathrm{C}_{19} \mathrm{H}_{18} \mathrm{BrNO}_{4}$ ).

5i. $80 \%$ (based on conversion), mp $182-184{ }^{0} \mathrm{C}$; IR (KBr) $v_{\max } 3029,2943,1762,1591 \mathrm{~cm}^{-1} ;{ }^{1} \mathrm{H}$ NMR $\left(300 \mathrm{MHz}, \mathrm{CDCl}_{3}\right) \delta 9.29(1 \mathrm{H}, \mathrm{d}, \mathrm{J}=9.3 \mathrm{~Hz}), 8.93(1 \mathrm{H}, \mathrm{s}), 8.12-7.22(23 \mathrm{H}, \mathrm{m}), 6.11(1 \mathrm{H}$, s), $6.03(2 \mathrm{H}, \mathrm{t}, \mathrm{J}=6.3 \mathrm{~Hz}), 5.82-5.74(3 \mathrm{H}, \mathrm{m}), 5.56(1 \mathrm{H}, \mathrm{d}, \mathrm{J}=7.2 \mathrm{~Hz}), 4.73(2 \mathrm{H}, \mathrm{t}, \mathrm{J}=6.3 \mathrm{~Hz})$, $3.89(3 \mathrm{H}, \mathrm{s}), 1.83-1.79(2 \mathrm{H}, \mathrm{m}), 1.52-1.42(2 \mathrm{H}, \mathrm{m}), 0.96(3 \mathrm{H}, \mathrm{t}, \mathrm{J}=7.2 \mathrm{~Hz}) ; \mathrm{FAB}-\mathrm{MS}: \mathrm{m} / \mathrm{z}$ Calcd for $\mathrm{C}_{53} \mathrm{H}_{45} \mathrm{NO}_{13}$ : 903.303. Found: 903.298 .

5j. $75 \%$ (based on conversion), mp 196-198 ${ }^{0} \mathrm{C}$; IR (KBr) $v_{\max } 2996,1732,1610 \mathrm{~cm}^{-1}$; ${ }^{1} \mathrm{H}$ NMR $\left(300 \mathrm{MHz}, \mathrm{MeOH}-\mathrm{d}_{4}\right) \delta 9.16(1 \mathrm{H}, \mathrm{d}, \mathrm{J}=8.9 \mathrm{~Hz}), 8.49(1 \mathrm{H}, \mathrm{d}, \mathrm{J}=9.0 \mathrm{~Hz}), 8.41(1 \mathrm{H}, \mathrm{d}, \mathrm{J}=9.3$ $\mathrm{Hz}), 8.08(1 \mathrm{H}, \mathrm{s}), 7.78(1 \mathrm{H}, \mathrm{d}, \mathrm{J}=8.4 \mathrm{~Hz}), 6.21-6.17(1 \mathrm{H}, \mathrm{m}), 6.11-6.08(1 \mathrm{H}, \mathrm{m}), 5.94-5.84(3 \mathrm{H}$, $\mathrm{m})$, 5.32-5.28 $(1 \mathrm{H}, \mathrm{m}), 4.96-4.92(1 \mathrm{H}, \mathrm{m}), 4.74-4.71(1 \mathrm{H}, \mathrm{m}), 4.21-1.02(12 \mathrm{H}, \mathrm{m})$; FAB-MS: $\mathrm{m} / \mathrm{z}$ Calcd for $\mathrm{C}_{25} \mathrm{H}_{29} \mathrm{NO}_{9}$ : 487.199. Found: 487.192 .

5k. 95\% (based on conversion), mp 201-203 ${ }^{0} \mathrm{C}$; IR (KBr) $v_{\max } 2945,1762,1539,1232 \mathrm{~cm}^{-1} ;{ }^{1} \mathrm{H}$ NMR $\left(300 \mathrm{MHz}, \mathrm{CDCl}_{3}\right) \delta 8.57(1 \mathrm{H}, \mathrm{d}, \mathrm{J}=9.6 \mathrm{~Hz}), 7.32-7.26(4 \mathrm{H}, \mathrm{m}), 5.43(1 \mathrm{H}, \mathrm{s}), 5.25(1 \mathrm{H}$, s), 4.84-4.81 (2H, m), $4.61(1 \mathrm{H}, \mathrm{s}), 3.65(3 \mathrm{H}, \mathrm{s}), 2.50(2 \mathrm{H}, \mathrm{d}, \mathrm{J}=6.3 \mathrm{~Hz}), 2.01-0.90(48 \mathrm{H}, \mathrm{m})$; FAB-MS: $\mathrm{m} / \mathrm{z}$ Calcd for $\mathrm{C}_{47} \mathrm{H}_{63} \mathrm{NO}_{6}$ : 738.006. Found: 738.001 .

\section{General procedure for the synthesis of the symmetrical squaraine dyes 6e-f and 6i-k}

A mixture of the corresponding quinaldinium salt $(0.06 \mathrm{mmol})$, and squaric acid $(0.03 \mathrm{mmol})$ and quinoline $(0.5 \mathrm{~mL})$ was refluxed in a mixture of n-butanol and benzene $(6 \mathrm{~mL}$ each, $1: 1)$ with azeotropic distillation of water for $24 \mathrm{~h}$. The solvent was distilled off under reduced pressure to obtain a residue which was chromatographed over silica gel. Elution of the column with a mixture (1:9) of methanol and chloroform gave the corresponding squaraine dyes.

6e. $86 \%$, mp 336-338 ${ }^{0} \mathrm{C}$, IR (KBr) $v_{\max } 3056,1613,1580 \mathrm{~cm}^{-1} .{ }^{1} \mathrm{H}-\mathrm{NMR}$ (DMSO-d 6 ) $\delta 9.31$ $(1 \mathrm{H}, \mathrm{d}, \mathrm{J}=9.5 \mathrm{~Hz}), 9.28(1 \mathrm{H}, \mathrm{d}, \mathrm{J}=9.3 \mathrm{~Hz}), 7.3-8.4(8 \mathrm{H}, \mathrm{m}$, aromatic), $5.86(1 \mathrm{H}, \mathrm{s}$, olefinic), $5.78(1 \mathrm{H}, \mathrm{s}$, olefinic), $3.85(3 \mathrm{H}, \mathrm{s}) ; 3.78(3 \mathrm{H}, \mathrm{s}) ; \mathrm{FAB}-\mathrm{MS}: \mathrm{m} / \mathrm{z}=550.246$ (calcd 550.248 for $\mathrm{C}_{26} \mathrm{H}_{18} \mathrm{Br}_{2} \mathrm{~N}_{2} \mathrm{O}_{2}$ ).

6f. $85 \%, \mathrm{mp} 314-315{ }^{0} \mathrm{C}$, IR (KBr) $v_{\max } 2962,1620,1553 \mathrm{~cm}^{-1} .{ }^{1} \mathrm{H}-\mathrm{NMR}\left(\mathrm{DMSO}_{-} \mathrm{d}_{6}\right) \delta 9.23$ $(1 \mathrm{H}, \mathrm{d}, \mathrm{J}=9.4 \mathrm{~Hz}), 9.19(1 \mathrm{H}, \mathrm{d}, \mathrm{J}=9.2 \mathrm{~Hz}), 7.1-8.05(8 \mathrm{H}, \mathrm{m}$, aromatic $), 5.89(1 \mathrm{H}, \mathrm{s}$, olefinic $)$, $5.72(1 \mathrm{H}, \mathrm{s}$, olefinic), $3.81(3 \mathrm{H}, \mathrm{s}), 3.71(3 \mathrm{H}, \mathrm{s}) ; \mathrm{FAB}-\mathrm{MS}: \mathrm{m} / \mathrm{z}=643.944$ (calcd 643.946 for $\mathrm{C}_{26} \mathrm{H}_{18} \mathrm{I}_{2} \mathrm{~N}_{2} \mathrm{O}_{2}$ ).

6i. $(10 \%)$ : $\mathrm{mp} 219-220{ }^{0} \mathrm{C}$, IR (KBr) $v_{\max } 3066,2954,1732,1575,1494 \mathrm{~cm}^{-1} ;{ }^{1} \mathrm{H}$ NMR $(300$ $\left.\mathrm{MHz}, \mathrm{CDCl}_{3}\right) \delta 9.17(2 \mathrm{H}, \mathrm{d}, \mathrm{J}=9.3 \mathrm{~Hz}), 7.98-7.86(13 \mathrm{H}, \mathrm{m}$, aromatic), 7.53-7.02 $(31 \mathrm{H}, \mathrm{m}$, aromatic), 7.44-7.30 $(4 \mathrm{H}, \mathrm{m}$, aromatic), 6.01-5.94 $(3 \mathrm{H}, \mathrm{m}), 5.79-5.73(7 \mathrm{H}, \mathrm{m}), 5.46(1 \mathrm{H}, \mathrm{s})$, 4.67- $4.59(5 \mathrm{H}, \mathrm{m}), 4.17$ (2H. s), $3.62(6 \mathrm{H}, \mathrm{s})$; FAB-MS: m/z Calcd for $\mathrm{C}_{94} \mathrm{H}_{72} \mathrm{~N}_{2} \mathrm{O}_{13}: 1580.488$. Found: 1580.492 .

6k. (80\%): mp 297-298 ${ }^{0} \mathrm{C}$, IR (KBr) $v_{\max } 2947,2943,1757,1613,1566 \mathrm{~cm}^{-1} ;{ }^{1} \mathrm{H}$ NMR (300 $\left.\mathrm{MHz}, \mathrm{CDCl}_{3}\right) \delta 9.31(2 \mathrm{H}, \mathrm{d}, \mathrm{J}=9.6 \mathrm{~Hz}), 7.44-7.30(8 \mathrm{H}, \mathrm{m}$, aromatic), $5.80(2 \mathrm{H}, \mathrm{s}$, olefinic), 5.43 
$(2 \mathrm{H}, \mathrm{s}), 4.60(2 \mathrm{H}, \mathrm{s}), 3.79(6 \mathrm{H}, \mathrm{s}), 2.50(6 \mathrm{H}, \mathrm{s}) ; 2.04-0.69(83 \mathrm{H}, \mathrm{m}) ; \mathrm{FAB}-\mathrm{MS}: \mathrm{m} / \mathrm{z}$ Calcd for $\mathrm{C}_{82} \mathrm{H}_{108} \mathrm{~N}_{2} \mathrm{O}_{8}: 1248.842$. Found: 1248.846 .

\section{General procedure for the synthesis of the symmetrical squaraine dyes $6 \mathrm{~g}-\mathrm{h}$}

A mixture of the corresponding quinaldinium salt $(0.06 \mathrm{mmol})$, and squaric acid $(0.03 \mathrm{mmol})$, tributylorthoformate $(0.5 \mathrm{~mL})$ and quinoline $(0.5 \mathrm{~mL})$ was heated in n-butanol $(6 \mathrm{~mL}$ each, $1: 1)$ at $60-70{ }^{0} \mathrm{C}$ for $6 \mathrm{~h}$. The solvent was distilled off under reduced pressure to obtain a residue which was then thoroughly washed with methanol to give the corresponding squaraine dyes $\mathbf{6 g}-\mathbf{h}$ in good yields (calculated based on conversion).

6g. $86 \%$, mp 290-292 ${ }^{0} \mathrm{C}$, IR (KBr) $v_{\max } 3032,1616,1579 \mathrm{~cm}^{-1} .{ }^{1} \mathrm{H}-\mathrm{NMR}$ (DMSO-d 6 ) $\delta 9.49$ $(1 \mathrm{H}, \mathrm{d}, \quad \mathrm{J}=9.4 \mathrm{~Hz}), 9.45(1 \mathrm{H}, \mathrm{d}, \mathrm{J}=9.5 \mathrm{~Hz}), 7.4-8.27$ (8H, m, aromatic), $5.92(1 \mathrm{H}$, s, olefinic), $5.85(1 \mathrm{H}, \mathrm{s}$, olefinic), $3.92(3 \mathrm{H}, \mathrm{s}), 3.84(3 \mathrm{H}, \mathrm{s}) ; \mathrm{FAB}-\mathrm{MS}: \mathrm{m} / \mathrm{z}=498.149$ (calcd 498.150 for $\mathrm{C}_{27} \mathrm{H}_{22} \mathrm{~N}_{4} \mathrm{O}_{6}$ ).

6h. 84\%, mp 306-308 ${ }^{0} \mathrm{C}$, IR $v_{\max }(\mathrm{KBr}) 3029,2225,1602 \mathrm{~cm}^{-1} ;{ }^{1} \mathrm{H}-\mathrm{NMR}\left(\mathrm{DMSO}-\mathrm{d}_{6}\right) \delta 9.39$ $(1 \mathrm{H}, \mathrm{d}, \quad \mathrm{J}=8.9 \mathrm{~Hz}), 9.42(1 \mathrm{H}, \mathrm{d}, \mathrm{J}=9.4 \mathrm{~Hz}), 7.35-8.28(8 \mathrm{H}, \mathrm{m}$, aromatic $), 5.87(1 \mathrm{H}, \mathrm{s}$, olefinic), $5.79(1 \mathrm{H}, \mathrm{s}$, olefinic), $3.95(3 \mathrm{H}, \mathrm{s}), 3.82(3 \mathrm{H}, \mathrm{s})$; FAB-MS: m/z = 442.472 (calcd 442.470 for $\mathrm{C}_{28} \mathrm{H}_{18} \mathrm{~N}_{4} \mathrm{O}_{2}$ ).

\section{General procedure for the synthesis of the unsymmetrical squaraine dyes 7i-k}

A mixture of the corresponding semisquaraine $(0.06 \mathrm{mmol})$ and the quinaldinium salt $\mathbf{4 f}(0.06$ $\mathrm{mmol})$, and quinoline $(0.5 \mathrm{~mL})$ was refluxed in a mixture of $n$-butanol and benzene $(6 \mathrm{~mL}$ each, $1: 1)$ for $12 \mathrm{~h}$. The solvent was distilled off under reduced pressure to obtain a residue which was chromatographed over silica gel. Elution of the column with a mixture (1:9) of methanol and chloroform gave the corresponding squaraine dye.

7i. (76\%): $\operatorname{mp~} 347-348{ }^{0} \mathrm{C}$; IR (KBr) $v_{\max } 2962,1730,1614,1572,1554 \mathrm{~cm}^{-1} ;{ }^{1} \mathrm{H}$ NMR $(300$ $\left.\mathrm{MHz}, \mathrm{CDCl}_{3}\right) \delta 9.18(1 \mathrm{H}, \mathrm{d}, \mathrm{J}=9.2 \mathrm{~Hz}), 9.01(1 \mathrm{H}, \mathrm{d}, \mathrm{J}=9.1 \mathrm{~Hz}), 8.06-7.85(14 \mathrm{H}, \mathrm{m}), 7.51-7.30$ $(14 \mathrm{H}, \mathrm{m}), 6.10-6.02(2 \mathrm{H}, \mathrm{m}), 5.99-5.90(2 \mathrm{H}, \mathrm{m}), 5.02-4.95(3 \mathrm{H}, \mathrm{m}), 4.88-4.83(1 \mathrm{H}, \mathrm{m}), 4.54-$ $4.50(1 \mathrm{H}, \mathrm{m}), 3.92(6 \mathrm{H}, \mathrm{s})$; FAB-MS: m/z Calcd for $\mathrm{C}_{60} \mathrm{H}_{45} \mathrm{IN}_{2} \mathrm{O}_{12}: 1112.217$. Found: 1112.210.

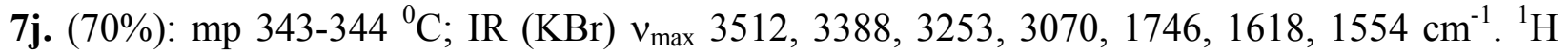
NMR (300 MHz, DMSO-d $) \delta 9.25(1 \mathrm{H}, \mathrm{d}, \mathrm{J}=9.1 \mathrm{~Hz}), 9.13(1 \mathrm{H}, \mathrm{d}, \mathrm{J}=9.5 \mathrm{~Hz}), 7.98-7.90(3 \mathrm{H}$, m), 7.46-7.4 (5H, m), $6.22(1 \mathrm{H}, \mathrm{s}), 6.18(1 \mathrm{H}, \mathrm{s}), 6.10-5.98(3 \mathrm{H}, \mathrm{m}), 5.21-5.12(3 \mathrm{H}, \mathrm{m}), 4.88-4.84$ $(1 \mathrm{H}, \mathrm{m}), 3.92(6 \mathrm{H}, \mathrm{s})$; FAB-MS: m/z Calcd for $\mathrm{C}_{32} \mathrm{H}_{29} \mathrm{IN}_{2} \mathrm{O}_{8}$ : 696.118. Found: 696.112.

7k. $(80 \%)$ : $\operatorname{mp} 295-296{ }^{0} \mathrm{C}$; IR $(\mathrm{KBr}) v_{\max } 3064,1759,1693,1618,1552 \mathrm{~cm}^{-1}$; ${ }^{1} \mathrm{H}$ NMR $(300$ $\left.\mathrm{MHz}_{\mathrm{CDCl}}\right) \delta 9.3(1 \mathrm{H}, \mathrm{d}, \mathrm{J}=9.2 \mathrm{~Hz}), 9.24(1 \mathrm{H}, \mathrm{d}, \mathrm{J}=9.1 \mathrm{~Hz}), 7.76-7.72(3 \mathrm{H}, \mathrm{m}), 7.37-7.29$ $(4 \mathrm{H}, \mathrm{m}), 7.09(1 \mathrm{H}, \mathrm{s}), 5.75(1 \mathrm{H}, \mathrm{s}), 5.45(1 \mathrm{H}, \mathrm{s}), 4.61(1 \mathrm{H}, \mathrm{s}), 3.78(3 \mathrm{H}, \mathrm{s}), 3.70(3 \mathrm{H}, \mathrm{s}), 3.51$ $(3 \mathrm{H}, \mathrm{s}), 2.52-2.47(2 \mathrm{H}, \mathrm{m}), 2.04-0.71(39 \mathrm{H}, \mathrm{m})$; FAB-MS: m/z Calcd for $\mathrm{C}_{54} \mathrm{H}_{63} \mathrm{IN}_{2} \mathrm{O}_{5}$ : 946.394 . Found: 946.388. 


\section{Acknowledgements}

We thank Professor Waldemar Adam for generously providing squaric acid and the Council of Scientific and Industrial Research and Department of Science and Technology, Government of India for the financial support of this work. This is contribution No. RRLT-PPD-231 from the Regional Research Laboratory (CSIR), Trivandrum, India.

\section{References and Footnotes}

1. (a) Dougherty, T. J. Photochem. Photobiol. 1987, 45, 879. (b) Bonnett, R. Chem. Soc. Rev. 1995, 24, 19. (c) MacRobert, A. J.; Philips, D. Chem. Ind. 1992, 17.

2. (a) Kessel, D. Photodynamic Therapy of Neoplastic Disease; CRC Press: Boca Raton, FL, 1990; Vol. 2. (b) Bonnett, R. Chemical Aspects of Photodynamic Therapy; Gordon and Breach Science Publishers: The Netherlands, 2000.

3. (a) Moan, J.; Berg, K. Photochem. Photobiol. 1992, 55, 931. (b) Gomer, C. J. Photochem. Photobiol. 1991, 54, 1093. (c) Brown, S. B.; Truscott, T. G. Chem. Br. 1993, $29,955$.

4. (a) Fiery, P. A.; Ford, W. E.; Sounik, J. R.; Kenney, M. E.; Rodgers, M. A. J. J. Am. Chem. Soc. 1988, 110, 7626. (b) Jori, G.; Spikes, D. In Topics in Photomedicine; Smith, K. C. Ed.; Plenum Publishing Corp.: New York, 1984; p 183.

5. Moser, J. G. Photodynamic Tumor Therapy: $2^{\text {nd }}$ and $3^{\text {rd }}$ Generation Photosensitizers; Harwood Academic Publishers: Amsterdam, 1998.

6. Levy, J. G. Trends Biotechnol. 1995, 13, 14.

7. (a) Law, K. Y. J. Phys. Chem. 1987, 91, 5184. (b) Emmelius, M.; Pawlowski, G.; Vollmann, H. W. Angew. Chem., Int. Ed. Engl. 1989, 28, 1445. (c) Law, K. Y. Chem. Rev. 1993, 93, 449.

8. (a) Das, S.; Thomas, K. G.; George, M. V. Mol. Supramol. Photochem. 1997, 1, 467. (b) Chen, H.; Farahat, M. S.; Law, K. Y.; Whitten, D. G. J. Am. Chem. Soc. 1996, 118, 2584.

9. Fabian, J.; Nakazumi, H.; Matsuoka, M. Chem. Rev. 1992, 92, 1197. (b) Emmelius, M.; Pawlowski, G.; Vollmann, H. W. Angew. Chem., Int. Ed.1989, 28, 1445.

10. Law, K. Y.; Bailey, F. C. J. Imaging Sci. 1987, 31, 172.

11. (a) Chen, C. T.; Marder, S. R.; Cheng, L. T. Chem. Comm. 1994, 259. (b) Ashwell, G. J.; Jefferies, G.; Hamilton, D. G.; Lynch, D. E.; Roberts, M. P. S.; Bahra, G. S.; Brown, C. R. Nature 1995, 375, 385.

12. (a) Ros-Lis, J. V.; Garcia, B.; Jimenez, D.; Martinez-Manez, R.; Sancenon, F.; Soto, J.; Gonzalvo, F.; Valldecabres, M. C. J. Am. Chem. Soc. 2004, 126, 4064. (b) Arunkumar, E.; Ajayaghosh, A.; Daub, J. J. Am. Chem. Soc. 2005, 127, 3156.

13. Jisha, V. S.; Arun, K. T.; Hariharan, M.; Ramaiah, D. J. Am. Chem. Soc. 2006, 128, 6024. 
14. (a) Ramaiah, D.; Joy, A.; Chandrasekhar, N.; Eldho, N. V.; Das, S.; George, M. V. Photochem. Photobiol. 1997, 65, 783. (b) Arun, K. T.; Epe, B.; Ramaiah, D. J. Phys. Chem. B 2002, 106, 11622. (c) Arun, K. T.; Ramaiah, D. J. Phys. Chem. A 2005, 109, 5571.

15. (a) Ramaiah, D.; Eckert, I.; Arun, K. T.; Weidenfeller, L.; Epe, B. Photochem. Photobiol. 2002, 76, 672. (b) Ramaiah, D.; Eckert, I.; Arun, K. T.; Weidenfeller, L.; Epe, B. Photochem. Photobiol. 2004, 79, 99. (c) Ramaiah, D.; Arun. K. T.; Das, S.; Epe, B. US Patent 6,770,787, 2004.

16. Bernstein, J.; Tristani-Kendra, M.; Eckhardt, C. J. J. Phys. Chem. 1986, 90, 1069.

17. (a) Treibs, A.; Jacob, K. Angew. Chem. Int. Ed. Engl. 1965, 4, 694. (b) Schmidt, A. H. Synthesis 1980, 961.

18. (a) Jyothish, K.; Arun, K. T.; Ramaiah, D. Org. Lett. 2004, 6, 3965. (b) Jyothish, K.; Avirah, R. R.; Ramaiah, D. Org. Lett. 2006, 8, 111.

19. All geometries were optimized using semiemperical AM1 calculations. DFT B3LYP/6-31G* single-point energy calculations were used to obtain the electrostatic potential surfaces using Titan (Wavefunction, Inc.).

20. (a) Joseph, J.; Eldho, N. V.; Ramaiah, D. Chem. Eur. J. 2003, 9, 5926. (b) Joseph, J.; Eldho, N. V.; Ramaiah, D. J. Phys. Chem. B 2003, 107, 4444. (c) Kuruvilla, E.; Joseph, J.; Ramaiah, D. J. Phys. Chem. B 2005, 109, 21997.

21. (a) Jones, G. Ed. The Chemistry of Heterocyclic Compounds, Part I, Interscience Publishers: Great Britain, 1977. (b) Spivey, A. M.; Curd, F. H. S. J. Chem. Soc. 1949, 2656. (c) Leir, C. M. J. Org. Chem. 1977, 42, 911. 